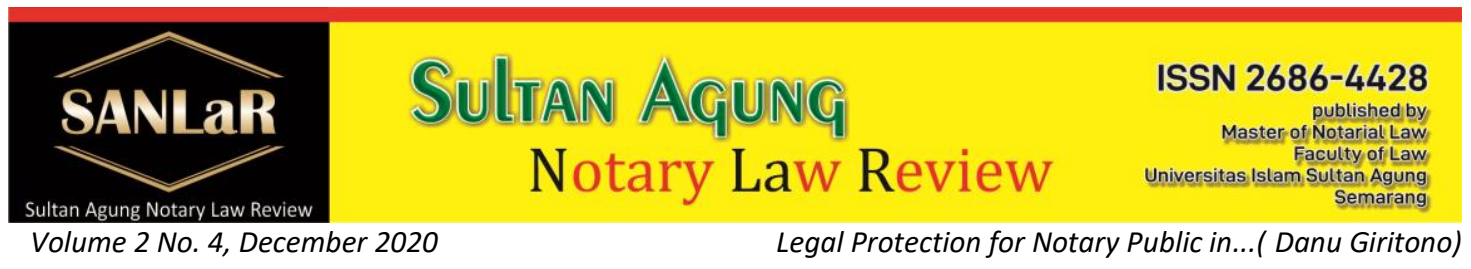

\title{
Legal Protection for Notary Public in Performing Their Duties As A General Officer Based on Law of Notary Office in Kendari Region
}

\author{
Danu Giritono*) \\ ${ }^{*}$ S Students of Master of Notary Law, Universitas Islam Sultan Agung (UNISSULA) \\ Semarang
}

\begin{abstract}
This research was conducted using a normative juridical or statutory approach. With the aim of approaching the problem by looking at the prevailing laws and regulations regarding legal protection against notaries for data forgery by clients in the Kendari city area. Forms of legal protection for Notaries in the city area, although in making authentic deeds, they must pay attention to the principles of prudence, thoroughness, and uphold honesty, morality and not forgetting professionalism. Meanwhile, the form of legal protection from the Notary Honorary Council is to carry out supervision and examination for Notaries so that they can continue to walk on the right path in accordance with the Law. When a Notary is summoned in a criminal case, the MKN has the authority to agree to be examined or not to be examined as long as the Notary has acted in accordance with UUJN and/or the relevant laws and regulations in connection with the deed made before him, MKN should not give the Notary's approval to be examined or attend the trial.
\end{abstract}

Keywords: Legal Protection; Notary; UUJN.

\section{Introduction}

The needs of the people in the Kendari city area for legal certainty are very important in life so that every element in society that is related directly or indirectly to implementing and enforcing the law must have the same parameters, namely achieving legal certainty.

The increasing need for legal certainty guarantees the consequent need for the existence of a notary to make deeds in all aspects of legal acts committed by the public. Notary profession is very important because of the nature and nature of the work of a notary which is very oriented towards legalization, so that it can become the main legal foundation regarding the status of assets, rights and obligations of the parties. In carrying out his duties and positions, a notary must adhere to the Code of Ethics for the Position of a Notary.

As referred to in Article 1 paragraph (1) of Act No. 30 of 2004 in conjunction with Act No. 2 of 2014 concerning the Position of Notary Public: "Notary is a Public Official who has the authority to make an Authentic Deed and other powers as referred to in this law". 
Notary profession is a profession that provides services to the public to make evidence in the form of deeds so that notaries do not take sides in one of the parties and must be fair to both parties and explain the consequences of the agreement they make on each of them.

In addition, the notary is also the only public official appointed to make the evidence, so that the notary does not commit any acts committed by the parties but only makes evidence for both parties.

Legal products issued by notaries are deeds that have authentic characteristics and have perfect evidentiary power. The duties and powers of a notary are closely related to agreements, deeds, and also provisions that give rise to rights and obligations between the parties, namely to provide guarantees or evidence of acts, agreements, and also these provisions so that the parties involved in it have legal certainty.

Based on article 15 paragraph (1-3) Act No. 30 of 2004 in conjunction with Act No. 2 of 2014 concerning the position of notary, it is stated:

1. The notary is authorized to make authentic deeds regarding all deeds, agreements, and provisions required by the laws and regulations and/or that the interested party wants to be stated in the authentic deed, guarantees the certainty of the date of making the deed, keeps the deed, gives grosse, copied and excerpts from deeds, all of it as long as the word deed is not affirmed or excluded from other officials stipulated by law.

2. The notary is also authorized:

a. Ratify signatures and set a certain date of the letter under the hand by registering in a special book.

b. Record letters under hand by registering in a special book.

c. Make a copy of a letter under hand in the form of a copy which contains the description as written and described in the letter concerned.

d. Conduct validation of the compatibility of the photocopy with the original letter.

e. Providing legal education in connection with making deeds.

f. Making deeds related to defense.

g. Prepare a deed of auction minutes

3. Apart from the authorities as referred to in paragraph (1) and paragraph (2), the notary public has other powers that are regulated in the statutory regulations.

The philosophical basis for the formation of Act No. 30 of 2004 concerning the Position of Notary Public is the realization of a guarantee of legal certainty, order and legal protection which is based on truth and justice through deeds that he makes, notaries must be able to provide legal certainty to the public who uses notary services. Legal products issued by a notary are in the form of deeds that have authentic characteristics and have perfect evidentiary power. As the definition of an authentic deed as stated in article 1868 of the Civil Code, an 
authentic deed is a deed which in the form determined by law is made by or in front of public officials who are in power for it to be placed where the deed was made.

Basically, when the rules of notary position above apply, it can still be said that very few notaries have been sued or sued by clients or third parties. Since the enactment of Act No. 30 of 2004 concerning the Position of Notary which was ratified or promulgated on October 6,2004 , all notaries in carrying out their positions must obey and be loyal to the Law on Notary Position. Since the enactment of this new Notary Position Law, many notaries have always been summoned and examined as both witnesses and suspects.

\section{Research methods}

This research is a normative legal research. Normative legal research is research conducted by analyzing written law from library materials or secondary data, known as secondary materials and reference materials in the legal field or legal reference materials. Normative legal research is intended to approach the problem by looking at it from the point of view of the prevailing laws and doctrines. In this study, normative legal research aims to examine the legal protection of notaries.

\section{Results and Discussion}

\subsection{Legal protection for Notaries according to the Law on the Position of Notary Public}

The Law on Notary Position acknowledges the existence of a Notary who acts as a public official, who carries out all his/her duties needs to obtain legal protection, namely a Notary as an office, not a Notary as a person.

Legal protection of the rights of notaries is a result of the transformation of interests carried out through a legislative process in safeguarding lawmakers or parliament, so that the rights of notaries must be respected, or protected and obeyed. The Law on Notary Position has regulated the form of legal protection that can be given to Notaries who carry out their duties as a public official, this is reflected or express in Article 66 paragraph (1), (2) UUJN regarding the with drawal of deed minutes and notaries who state:

1). For the purposes of judicial proceedings, investigators, public prosecutors, or judges with the approval of the Notary Honorary Council are authorized: See Article 66 of the Law on Notary Position.

a. Take a photocopy of the minimum deed and/or letters attached to the Minuta deed or Notary Protocol in the notary's deposit; and

b. Calling the Notary Public to be present in the examination related to the deed he made or the Notary Protocol that is in the Notary's storage. 
c. Taking photocopies of the minimum deeds or letters as referred to in paragraph (1) letter a, an official report of the submission is made.

In UUJN there is no legal protection for notaries except for Ingkar's right, but we use the law in general if an innocent person cannot be punished and cannot be sued. Actually, notaries do not take refuge in UUJN. Notaries take refuge in their own behavior. What we have done is already protected by law.

So far, the principle of "lex specialist derogat legi generali" (special law is won against general law) so that in fact UUJN which clearly regulates specifically intended for Notaries should be won against the Criminal Code (which is generally accepted law), but in practice it is not thus.

Defending the right of denial and obligations of denial must also be respected. Only the judiciary and the police have the right to summon the relevant notary. In practice the police can forcibly summon but with the first step to ask permission or approval from MKN, if MKN does not allow or approve, let MKN deal with the police.

\subsection{Legal Protection for Notaries According to the Notary Honorary Council}

Before Act No. 2 of 2014 concerning Amendments to Act No. 30 of 2004 concerning the Law on the Position of Notary Public is promulgated, the examination of Notaries by law enforcement officials for the benefit of the judicial process must be carried out with the approval of the Regional Supervisory Council (MPD). The Regional Supervisory Council is the Supervisory Council formed by the Minister in the framework of exercising its authority to carry out supervision over Notaries at the regency or city level. This authority was later abolished by the Constitutional Court Decision Number 49/PUU-X/2012 which in its decision decided to remove the phrase "With the approval of the Regional Supervisory Council" contained in Article 66 paragraph (1) of Act No. 30 of 2004 concerning the Position of Notary Public.

After the promulgation of Act No. 2 of 2014 concerning amendments to Act No. 30 of 2004 concerning the Law on Notary Position, the authority to grant approval for Notary examination for the benefit of the judicial process by law is given to the Notary Honorary Council (MKN).

The Notary Honorary Council is an institution that is mandated by the Law to be formed by the Minister in order to carry out guidance as stipulated in Article $66 \mathrm{~A}$ paragraph (1) of Act No. 2 of 2014 concerning Amendments to Act No. 30 of 2004 concerning Law Notary Position. To implement the provisions of Article 66 A paragraph (1) of Act No. 30 of 2004 concerning the position of a Notary as amended by Act No. 2 of 2014 concerning Amendments to Act No. 30 of 2004 concerning Notary Position, it is necessary to stipulate a Regulation of the Minister of Law and Human Rights regarding the Notary Honorary Council.

With the removal of the authority of the Regional Supervisory Council (MPD) in supervising Notaries, the supervisory authority for Notaries is given to the Notary Honorary Council. So that the Notary has control in carrying out his/her job duties and provides the Notary with legal protection in carrying out his/her job 
duties. Based on Article 66 A paragraph (1) UUJN-P, the Minister of Law and Human Rights issued Regulation of the Minister of Law and Human Rights of the Republic of Indonesia Number 7 of 2016 concerning the Notary Honorary Council. In Article 1 number 1 Regulation of the Minister of Law and Human Rights of the Republic of Indonesia Number 7 of 2016 defines the Notary Honorary Council:

The Notary Honor Council consists of:

a. Central MKN (formed by the Minister, domiciled in the state capital, DKI Jakarta); Central MKN has the task of fostering regional MKN in relation to its duties. In carrying out the task of fostering the Central MKN, it has the function of supervising regional MKN.

b. Regional MKN (established by the Director General on behalf of the Minister, domiciled in the provincial capital) Territorial MKN is in charge of examining applications submitted by investigators, public prosecutors and judges. Article 18 paragraph (1) letter $b$ states that the Regional MKN gives approval or rejection of the request for approval of a Notary's summons to attend investigations, prosecutions and judicial processes.

c. Assisted by the Secretariat of the Notary Honorary Council in charge of providing guidance for administration, human resources (HR), budget, and facilities and infrastructure.

In exercising its authority, MKN has the following characteristics:

1. Reactive, namely MKN acts when there is a request from investigators, public prosecutors and judges, as a result of the emergence of legal problems for Notaries and/or Notary's legal products.

2. Curative, namely the Regional MKN (based on the examination results of the Examining Council) has the authority to examine and locate legal issues that actually occur, in the event of a dispute and or a Notary's criminal act or a legal product made by a Notary.

Regional MKN in giving approval or rejection to investigators, public prosecutors and judges, must pay attention that if a criminal incident is clear and clear without the need for examination of a Notary as a witness (MKN Wilayah refuses) or vice versa without the testimony of a Notary on a criminal incident report or an incident. The incident occurred cannot be further processed so that a Notary's testimony is needed so that the criminal incident becomes clear and clear (MKN Wilayah gives approval).

The Regional MKN gives approval for the examination of a Notary as a suspect if the professional error is an error as an element of a criminal act, but on the contrary, if the professional error is not an element of a criminal act, the Regional MKN refuses. In conducting examination of Notaries, the Chairperson of the Regional Notary Honorary Council forms an Examining Council consisting of 3 (three) members consisting of each member of the Regional Notary Honorary Council consisting of:

a. 1 (one) Chairman who is also a Member; 
b. 2 (two) Members. The Examining Panel has the authority to examine and give approval or rejection of requests by investigators, public prosecutors, or judges for:

1) Taking photocopies of the minimum deeds and letters attached to the Minuta deeds and/or protocols of the Notary in the Notary's depository and the notary's summons;

2) Taking the Minutes of Deeds and letters attached to the Minutes of Deeds and/or Protocols of Notaries in the Notary's deposit and summons of Notaries;

3) Notary summons for law enforcement by investigators, public prosecutors, or judges.

The position of MKN in providing legal protection for Notaries is an independent institution, because in this case the existence of MKN is not a sub-part of the government that appointed it.

MKN in exercising its authority to issue a decision is not influenced by other parties or institutions, so that in this case the decision made by MKN cannot be contested.

Regarding the position of the MKN, it should be formed in stages starting from the district or city (regional), regional and central levels, this aims to avoid the accumulation of cases that enter and must be resolved through the MKN, and besides that, the MKN institution can be quickly responsive in providing decision to approve or reject requests from investigators related to taking photocopies of minuta deeds or notary summons itself for the benefit of the judicial process. This is because the Law only provides 30 (thirty) working days from the date the application is received.

If the time period has elapsed, the Notary Honorary Council will accept the request for approval. The existence of MKN which is formed in stages makes it possible to provide legal remedies for parties who feel aggrieved (notaries and investigators) to a higher level, namely through the Regional MKN and the Central MKN, by placing the results of the Regional MKN decisions as the object of examination. The results of decisions issued by the Central MKN are final decisions or cannot be contested. This is done because MKN is an independent body that issues decisions as the final result of the notary's examination.

Based on the description above, with the existence of a form of protection and a clear scope of authority from the MKN institution, it is hoped that it can provide clarity in providing legal protection for the notary institution, and can reinforce the existence of the MKN institution. It is also intended that the Notary Public Institution is not easily blamed by other parties related to deeds made by the Notary

The role of the Indonesian Notary Association (INI) in providing legal protection to members consists of:

1. Notary as a general official 
a. Notaries in carrying out their positions are not subject to the principle of equality before the law, as long as in carrying out their positions they have followed the procedures stipulated by law (Article 16 and Article 17 UUJN).

b. As long as it has implemented the provisions of the Law, then a claim in the form of an unlawful act based on Article 1365 BW cannot be made against a Notary, because the Notary has committed an act of controlling the intent/will of the parties who want the legal action they have committed and can be proven by a deed authentic.

2. Notary in civil suit

a. Notary in carrying out his/her position is only formal in nature as stated in the Jurisprudence of the Decision of the Supreme Court/MA Number $702 \mathrm{~K} / \mathrm{Sip} / 1973$ dated September 5, 1973. The notary only functions to record/write down what is desired and stated by the parties before the Notary Public. The notary is not obliged to investigate materially the matters brought up by the Notary public.

b. If the deed made before the Notary is problematic by the parties themselves, then it is the party's own business, the Notary does not need to be involved and the Notary is not a party to the deed.

c. The Notary Deed as an authentic deed has perfect evidentiary power, so that if there is a person/party who judges or states that the deed is incorrect or wants the person/party to deny the matters contained in the deed, then the person/party who assesses or states is obliged to prove the assessment or statement in accordance with the applicable legal regulations in Indonesia.

The Indonesian Notary Institute (INI), makes a legal construction of Notary Status:

1). Notary is not a Party to the deed

2). The notary only formulates the wishes of the parties so that their actions are stated in an authentic deed.

3). The Party's desire to make a deed will never come from a notary.

This is in accordance with the juridical character of the Notary and the Notary deed born from the three jurisprudence of the Supreme Court Decisions, namely: Decision of the Supreme Court of the Republic of Indonesia Number 702K/Sip/1973, dated 5 September 1973; Decision of the Supreme Court of the Republic of Indonesia Number 3199K/Pdt/1992, dated 27 October 1994; and Decision of the Supreme Court of the Republic of Indonesia Number $1140 \mathrm{~K} / \mathrm{Pdt} / 1996$, June 30, 1998. Based on this jurisdiction, the juridical characteristics of the Notary and the Notary deed are: First, the cancellation of a Notary deed by a judge cannot be justified, because the deed is the will of the parties. Second, that the function of a notary is only to record the wishes of the parties expressed before the notary. Third, the notary does not have material obligations for matters that are presented before the notary. Fourth, Notary 
deeds have perfect evidentiary power for the parties, their heirs and anyone who gets rights from the deed. Fifth, each Notary deed (or one Notary deed) contains only one legal action or act. If a Notary deed contains more than one legal act, then the deed has no executorial title and is invalid.

3. Notary in criminal charges

The Indonesian Notary Association (INI) assists in the investigation process as expert witnesses and assists legal advisors in preparing Pledoi for the benefit of members who are in trouble.

The Indonesian Notary Association (INI) does not provide legal protection, only provides assistance and defenses when a problem occurs. If the Notary Honorary Council (MKN) allows or does not allow the police to examine different fields, the MKN will not assist.

When a notary is allowed to be questioned by the police, don't think that the notary is called an investigator/police.

MKN's task is to give approval or reject requests from investigators, the Regional Police (Polda) or the High Prosecutor's Office (Kejati) or the District Court (PN) if for example it is appropriate to be granted approval permission but if not then with various considerations it is rejected. Legal protection must be based on provisions and legal rules that function to provide justice and serve as a means of creating welfare for all people.

Protection, justice and welfare are aimed at legal subjects, namely supporters of rights and obligations, including a notary. The notary's oath of office in Article 4 and the obligations of a Notary in Article 16 paragraph (1) letter (e) of the Notary Office Law obliges Notaries not to speak, even in court, meaning that a Notary is not allowed to testify regarding what is contained in the deed.

Based on Article 4 regarding the oath of office of a Notary and the obligations of a Notary in article 16 paragraph (1) letter e, the Notary Position Law requires Notaries not to speak, even though in court it means that a Notary is not allowed to give testimony/information regarding the content contained. In the deed.

The notary is not only entitled to speak, but has the obligation not to speak. This is in accordance with the explanation of Article 16 paragraph (1) letter (f) of the UUJN which states that: "keep everything about the deed made secret and all information obtained for making deeds in accordance with the notary oath of office".

The Law on Notary Position has provided law enforcement for the arbitrary actions of law enforcers against Notaries. This can be seen in Article 66 paragraph (1) UUJN with the existence of the Notary Honorary Council, as a legal protection institution for Notaries whose function is to carry out preliminary investigations in Notary organization sessions to give approval or rejection to investigators from the police, prosecutors, and judges who summon Notaries to be examined in the judicial process. 
In addition, MKN is also authorized to provide guidance to Notaries in carrying out their duties as public officials. Legal protection for Notaries is normatively provided by the prevailing laws and regulations, namely:

a. The formation of the Supervisory Council as mandated in Article 67 of the UUJN is formed by the Minister, which consists of 3 (three) elements, namely the government, notary organizations and academics. The supervision includes the implementation of the position of a Notary.

b. Regarding the procedure for taking the Minuta Deed and summoning the Notary, according to Article 66 of the UUJN which states: that in the interests of the judicial process, investigators, public prosecutors or judges with the approval of MKN are authorized to: take a photocopy of the Minuta Deed and letters attached to the Minuta deed. Summons the notary in examination related to the deed. This means that in conducting investigations, especially criminal cases, legal officers must go through a procedure for summons when the Notary Honorary Council does not approve, the Notary does not need to be present in the investigation process. This article provides legal protection for every Notary. c. Right to Remember Notary as regulated in: 1. Article 170 KUHAP; 2. Article 1909 number 3 Civil Code; 3. Article 146 paragraph (1) number 3 HIR; 4. Article 277 HIR; 5. Article 4 UUJN and Article 16 paragraph (1) letter e UUJN.

d. Memorandum of Understanding between the National Police of the Republic of Indonesia and the Indonesian Notary Association, Number 01/MOU/PPINI/V/2006 concerning Fostering and Enhancing Professionalism in the Field of Law Enforcement;

e. Central Supervisory Council Decree Number C-MPPN.03.10-15 concerning the Granting or Rejection of Approval for Notification Summons by investigators, public prosecutors or judges.

$\mathrm{f}$. Jurisprudence that can be used as a basis for consideration of several cases related to criminal acts faced by Notaries, namely the Supreme Court Decision Number $702 \mathrm{~K} / \mathrm{SIP} / 1973$, which in this case states that a Notary functions only to record/write down what he wants and stated by the parties before the Notary Public.

Notaries are not required to investigate materially against the statements desired by the tappers. Therefore, based on this Decision, the writer has analyzed and concluded that if the deed made before the Notary is problematic in the future, then the matter will fully become the responsibility of the parties, the Notary cannot be involved because the Notary is not a party to the deed.

Legal protection from the Regional Supervisory Council which is now the Notary's Honorary Council, namely providing supervision to Notaries so that the Notary will continue to work as a person who has a professional form of legal protection when the Notary has acted in accordance with UUJN and Notary's Professional Ethics, the Notary is not allowed to attend or be examined both as witnesses and as suspects. 
Notary professional organization, namely (INI) is considered to have more knowledge and understanding of the situation and practice of the Notary profession, so that professional violations committed by a Notary must first be examined by the Supervisory Panel before it is determined whether the violation in question is a personal violation or a professional violation.

Investigators and the Supervisory Board need to work together to provide legal protection for the Notary profession. From this organization, the part of its protection must be selected by a senior notary or Werdah Notary who is truly professional and ideal (Shiddiq, tabliq, amanah and fathonah). And there must be a guardianship that really provides legal protection and is able to lobby (in a positive sense) to law enforcers who are investigating Notaries.

The legal protection carried out by the Indonesian Notary Association or the socalled (INI) is accompanying the Notary Public during a Notary Court hearing when the Notary is guilty, he will accompany and provide legal assistance to the Notary Public. This will create a sense of calm, peace and guaranteed legal protection for Notaries in carrying out their duties as General Officials.

The notary will feel protected because all examination actions are carried out after careful examination and examination by the Supervisory Council as regulated in Article 66 of the UUJN, but the Supervisory Committee cannot provide any protection to a Notary who is proven guilty of carrying out the position of a Notary. With the public's trust in the position of a notary public, as a consequence, supervision must be guaranteed, so that the work and duties of the notary are always in accordance with the law that underlies their authority and in order to avoid abuse of authority or trust given to them.

Notaries should also uphold the Professional Code of Ethics that has been agreed upon by all members of the Notary as a basis for Notaries in their daily behavior.

\section{Closing}

\subsection{Conclusion}

1. Forms of legal protection for Notaries in the city area, although in making authentic deeds, they must pay attention to the principles of prudence, thoroughness, and uphold honesty, morality and not forgetting professionalism.

2. Meanwhile, the form of legal protection from the Notary Honorary Council is to supervise and examine Notaries so that they can continue to walk on the right path in accordance with the Law. When a Notary is summoned in a criminal case, the MKN has the authority to approve the examination or not to be examined as long as the Notary has acted in accordance with UUJN and/or related laws and regulations in connection with the deed made before him, MKN should not give the Notary's approval to be examined or attend the trial. As well as the form of legal protection from THIS in the form 
of an organ that is named the part of the protection that accompanies the Notary who is affected by the problem during the investigation and provides consultation and assistance in connection with the legal problems faced by the Notary concerned.

\subsection{Suggestion}

1. To the Notary, namely every time making a deed is not limited to the fulfillment of the formal truth but also endeavored to be up to the material truth and when summoned the Notary investigator remains silent and states that he is exercising his denial; To investigators, that is, if the Notary uses the right of denial or carries out the obligation to refuse, it is not deemed to have hampered the investigation process To the Notary Honorary Council (MKN) to be objective and professional in the sense that when the Notary in making deeds the parties/deed parties are in accordance with the deed making technique and do not violate UUJN and/or laws and regulations related views in the sense that the Notary has carried out his duties and obligations. As it should be, it should not be limited to always approving summons by investigators to the notary.

2. Notary as a public official in the Kendari city area in carrying out noble duties to help the community to provide legal education to their clients regarding the consequences and responsibilities of data, identity, and document contents brought by the client itself. Notary to always act carefully, be careful, and learn to improve his/her knowledge to explore the applicable laws and regulations properly during his/her position as a notary, so that there can be a minimum of deeds or deeds that are disputed by the parties concerned.

\section{References}

Books:

[1] Habib Adjie. (2009). Sekilas Dunia Notaris \& PPAT Indonesia (Kumpulan Tulisan). Cetakan Pertama. Bandung: Mandar Maju.

[2] . (2011), Kebatalan dan Pembatalan Akta Notaris. Cetakan Pertama. Bandung: Refika Aditama.

[3] (2011), Kompilasi Peraturan Perundang-Undangan Jabatan Notaris. Cetakan Pertama. Semarang: Pustaka Zaman.

[4] (2013), Menjalin Pemikiran -Pendapat Tentang Kenotariatan (Kumpulan Tulisan). Bandung: Citra Aditya Bakti. 

(2014), Merajut Pemikiran Dalam Dunia Notaris \& PPAT. Cetakan Kedua. Bandung: Citra Aditya Bakti.

[6] (2015). Penafsiran Tematik Hukum Notaris Indonesia. Bandung: Refika Aditama.

[7] . (2016), Kompilasi Persoalan Hukum Dalam Praktek Notaris Dan PPAT (Kapita Selekta Notaris \& PPAT) (1). Indonesia Notary Community (INC).

[8] Habib Adjie and Hafidh, Muhammad. (2016), Memahami: Majelis Kehormatan Notaris (MKN). Semarang: Sinergi Offset.

[9] Habib Adjie, Hafidh, Muhammad, and Fadli, Zul. (2016), Himpunan Putusan Mahkamah Konstitusi Republik Indonesia Mengenai UndangUndang Jabatan Notaris (UUJN). Semarang: Duta Nusindo.

[10] Ashofa, Burhan. (2001), Metode Penelitian Hukum. Jakarta: Rineka Cipta.

[11] Anshori, Abdul Ghofur. (2009). Lembaga Kenotariatan Indonesia; Perspektif Hukum dan Etika. Yogyakarta: UII Press.

[12] HS. Salim. (2016). Teknik Pembuatan Akta Satu (Konsep Teoretis, Kewenangan Notaris, Bentuk dan Minuta Akta). Cetakan Kedua. Jakarta: Raja Grafindo Persada.

[13] HR. Ridwan. (2008). Hukum Administrasi Negara. Jakarta: Raja Grafindo Persada.

[14] H. Adil. (2011). Mengenal Notaris Syari'ah. Citra Aditya Bakti: Bandung.

[15] Tobing, G.H.S. Lumban. (1992) , Peraturan Jabatan Notaris. Cetakan Ketiga. Jakarta: Erlangga. 